\title{
MILLENNIAL STUDENT EXPECTATIONS TOWARDS HIGHER EDUCATION IN LATVIA
}

Lasma Licite, Lana Janmere

Latvia University of Agriculture

lasma.licite@1lu.lv

\begin{abstract}
The learning habits of students in higher education are changing frequently and universities have to modify their learning environment to the needs of their students. The method of teaching ten years ago is not the method to achieve learning with Generation $\mathrm{Y}$ because Millennial students are quite opposite of their predecessors, Generation X. The aim of the research paper is to explore Millennial students' expectations towards higher education in Latvia. To achieve the aim, a survey of 179 Millennial students was conducted to determine the engineering student expectations from higher education in Latvia. The research showed that the students were relatively more in favour of the Millennial generation values rather than traditional values in higher education, yet their support was not absolute. The students demonstrated agreement with such essential aspects for the Millennial generation as the availability of technologies and the Internet for an effective study process, teaching personnel's knowledge of their discipline and ability to make students interested in a topic and give fast feedback. However, the students' opinions were not similar with regard to the roles of an academic and a student in the study process - in determining the content of a study course, a timetable of classes and the attendance of classes. Most of the students believed that they had to be given an opportunity to influence everything, while a third were rather in favour of the role of an academic as an authority in the study process. The differences in the values of the Millennial students in Latvia with regard to education may be partly explained by the fact that the Millennial generation in Latvia emerged only in the early 1990s, i.e. after the Soviet Union collapsed, and their value orientation has not yet become definite.
\end{abstract}

Keywords: Millennial student, higher education, Generation Y, Millennial generation.

\section{Introduction}

Each generation comes to university with varying characteristics that distinguish them from their predecessors. A new generation of learners has immersed themselves in the classroom - the Millennial generation or Gen Y [1]. They are determined, driven achievers, who depend on technology and their support system $[2 ; 3]$. Very often in the first years of their studies students realize that their needs of a learning environment in the university system are different from what they expected, and they quit their studies. It means that the learning habits of students in higher education are changing frequently and universities and colleges have to modify their learning environment to the needs of their students $[3 ; 4$; 5]. Student values and expectations towards higher education may be affected by different factors, including their previous educational experience, individual values etc. However, the authors focus on Millennial values and characteristics and their relevance to engineering students in Latvia.

According to scientific researches a paradigm shift is occurring, and higher education cannot ignore the needs of Millennial students [6; 7]. Therefore, the aim of the research paper is to explore Millennial students' expectations towards higher education in Latvia. To achieve the aim, the following specific research tasks were set: 1) to describe various characteristics of Millennial students that influence teaching and learning; 2) to identify Millennial student expectations from higher education in Latvia.

In the present research, a generation is defined as an 'identifiable group that shares birth years, age location, and significant life events at critical developmental stages' [8]. In the scientific literature, the Millennial generation or Gen Y is identified as a generation that has born from 1980 to 1999 [9] and their predecessors (Gen X) from 1965 to 1979 . However, in view of the fact that the characteristics and division of generations make major influences in the environment within which early human socialisation occurs, the Millennial generation emerged in Latvia only in the early 1990s, i.e. after the collapse of the Soviet Union. It is based on the fact that the characteristics and division of generations make major influences in the environment within which early human socialisation occurs [10]. For this reason, the research object is students that were born in the early 1990s and may be identified as Millennial students. According to scientific findings, Millennial students demonstrate the values and the way of thinking of Generation Y, whereas their predecessors have traditional values and a traditional perspective regarding higher education (the study process and the role of an academic in it). 


\section{Materials and methods}

The research was based on a questionnaire survey, in which engineering students were asked what their dream university should look like. The purpose of the questionnaire survey was to explore the engineering students' expectations towards higher education in Latvia. At present, the first phase of the survey is implemented - a pilot study at the Latvia University of Agriculture, which is the second largest university in Latvia, in which engineers of various fields are prepared and one of the objectives of which is the enhancement of quality of studies in STEM (Science, Technology, Engineering and Mathematics). Therefore, on the one hand, an examination of students' expectations is necessary for the purpose of identifying the values of the Millennial generation in higher education, while, on the other hand, it is an important step towards identifying the students' opinions and defining measures aimed at enhancing the quality of STEM studies.

The questionnaires were handed out to 179 first and second year students of different engineering programmes at the Latvia University of Agriculture and were collected back after being filled in. The survey period was from 10 December to 21 December 2016.

The questionnaire used 39 aspects of university performance as indicators to measure the student expectations, which involved the physical environment for studies, the performance of academics, the process of studies and the roles of fellow students and the family. Student expectations were measured on a semantic differential scale of seven categories, and each of the suggested 39 university aspects was expressed as a pair of two opposite assertions. In every pair of assertions, one of the assertions reflected the opinion of the Millennial generation about the university, while the other showed the values of Generation X. In this way, examining every pair of assertions allowed identifying the values of a generation which students associated themselves with. Choosing a category from 1 to 3 meant that students preferred the values of the Millennial generation, while the choice of a category from 5 to 7 indicated an opinion of someone from Generation X. However, the choice of a category numbered 4 indicated a neutral opinion, showing no concrete value preference. Central trend and dispersion indicators, i.e. the arithmetic mean and standard deviation were employed in processing and analysing the survey data.

\section{Results and discussion}

Characteristics of Millennial students. The Millennial Student is the largest and most diverse generation to ever attend university. They are unlike their predecessors, who attended college or university 10,15 , or 20 years ago [11]. Their collective personality, thought processes, and educational tendencies are unique to traditional educational practices and environments. Notable characteristics that define this generation are: lack of professional boundaries influenced by socialization, a need to have immediate feedback, a sense of entitlement, lack of critical thinking skills, unrealistic expectations, a high level of parental involvement, and an expected "how to" guide to succeed in and out of the classroom. The Millennials want to spend less time on tasks and reach success with little effort [12]. During the research, there were identified several characteristics of Millennial students regarding their expectations towards the study environment, the study process, lecturers, course mates and parents' role in the study process.

Physical environment. Learning environments are changing and learning is not based on a classroom anymore. Learning is happening anywhere and today's students are learning in diverse environments. Every place can become a learning atmosphere where knowledge can be discovered or reflected [7]. Students are not fixed on their classroom and their seat in the library [13]. They make their own decision where they want to do their study or work. Kahl's (2014) research shows that students dream of a digitized campus, where they can study at their pace and time. This includes a Wi-Fi system at the university, which supports students' need of being online [7]. In addition, enough and well equipped computer pools, where students can do their assignment. Students are technology mobilized [3; 14] and they are requesting the same for their study environment. Technology is the new learning tool and students are seeking to use this tool constantly.

Lecturers' role in a study process. Lecturers became more of motivators and entertainers instead of teachers [7]. Providing knowledge became a secondary criterion to teach students after keeping students interested on the subject. Especially with the short-term concentration span of Millennials, teaching 
needs to be modified [6]. Lecturers have to switch regularly to different teaching and learning methods to keep students concentrated on the subject and the course [15]. The best-proven way is through students' engagement in classes and in-deep discussions on the topic [16].

Students are also expecting of their "perfect" lecturer, who should be knowledgeable in their field. Knowledge means more than to know what is written in the textbook. Students are eagle to combine knowledge between classroom and industry [17]. That means, a lecturer also should know about practical use of knowledge in the industry.

Since students have a deep interest in technology, they are looking forward to have technology part of their classroom experiences $[3 ; 14]$. Students are also dreaming about more possibilities to do their assignments in study rooms outside on campus. Students want to stay in the university doing their assignment to ensure that they have fast access to resources (library) or support (lecturer/course mates). All the same, these study rooms should be opened 24 hours 7 days a week. Students prefer to control their pace and time through their study and dreaming of these 24/7 study rooms [7]. As research studies show, then an appetite for new technologies should be encouraged, not prohibited, and the educational system should take advantage of it [18].

Course mates and parents' role in a study process. Millennials feel they are special. This generation is comprised of students who have been taught that we are "all winners" just for participating. Millennials are more likely to be accompanied by their parents. These commonly called "helicopter" parents are much more involved with today's college student and desire to be part of their child's college life. Millennial parents want to be an integral part of decisions made concerning academic scheduling and extracurricular activities [2]. In the case of course mates, Millennials rely on recommendations from peers and friends more than from experts which refers to the course mates' importance of their lives [19].

Study process. Millennial students have changed the learning and teaching methods [20]. Active learning [21] became the framework of learning. Students are not passively listening to lecturers and taking notes. Learning happens through conversation and practical approaches. They prefer to be involved in the learning process and drive their learning via their interests [7]. Interest [6] of learning a subject became the central point in today's teaching and learning. It can be concluded that the higher education paradigm shifts from teacher-centered to learning-centered classrooms, so do the styles of communicating information to students. Educators provide the platform and mechanism for learning by effectively reaching students with content. In the past, content has been delivered with a traditional focus. The instructor was the "sage on stage" and completely controlled the learning environment by delivering content through lectures often using PowerPoint slides. Instructors using this type of delivery style will encounter more difficulty in reaching today's university students. Reaching this generation requires educators who better understand their audience and work in collaboration with their audience to use a variety of instructional delivery methods to engage students within their own learning process [22]. All information needs to be short and fast. Information is for proceeding through an event, and not for reflecting on it. Today's generation does not prefer to read long academic texts, instead they are looking for key points and discussing these points [23].

Also, Millennial students are less comfortable working independently. They are team oriented. Independent work has a higher risk of personal failure and, therefore, the Millennial students are not as confident working alone. As a result, students prefer to work cooperatively [24] on projects and participate within collaborative group settings.

Millennial student understanding of learning is based on different learning techniques and needs to be recognized, e.g. the practice of interactive teaching and student centered teaching in classrooms needs to be more intensively practice. These students are not willing to sit in a classroom for hours and listen to their lecturers. Learning needs to be more flexible and fun [7]. Gaining knowledge is not only based on textbooks, it becomes more a practice to use technological devices for research on knowledge and discuss a question via the Internet or social media [3]. Students instantly have information at their disposal through the Internet, text messaging, instant messaging, and other forms of telecommunication. They have total access to each other and information twenty-four hours a day, seven days a week (commonly referred to as 24/7) [22]. This has led to wanting instant access and immediacy in responses [22]. Emailing is considered extremely outdated due to response lag time. Instant messaging and text messaging provide the immediacy they want. They have been technologically stimulated throughout 
their childhood and demand this connectivity as they matriculate through university. Also, Millennial students are a generation that yearns for feedback. They thrive on constant feedback and become paralyzed, often unable to proceed forward, without feedback and direction.

Millennial student expectations towards higher education in Latvia. The ratings of the physical environment for studies by the engineering students demonstrated their agreement with the Millennial generation values, as they pointed out that amenities, the arrangement of seats in a room for studies, WiFi availability and an interactive blackboard were important for them. The average ratings of the mentioned aspects were in the range of 2.34-2.80. This indicates that in Latvia it is important for Millennial students to have an Internet connection and modern technologies available in the process of studies. Technologies, in the students' opinion, is a new learning tool and students are seeking to use this tool constantly. However, in a case where there is a choice between information available on a projector/screen and an inspirational story told by an academic (the average rating was 2.36), most of the students were in favour of the latter, pointing to the role of the human factor in the physical environment for studies. However, the arrangement of the physical environment was mainly viewed by the engineering students as a classical auditorium - an amphitheatre (the average rating was 4.73), in which the places of an academic and students are clearly separated. A round table, at which all could be seated, was less preferred by the students $(22 \%)$.

In characterising an ideal academic and his/her performance, the students stressed the availability of all materials for studies in the e-environment as the key priority (the average rating was 1.58). The average rating of this aspect was absolutely highest among all the aspects suggested in the survey, reflecting a characteristic of students as the Millennial generation - to study at a convenient time and place. As regards the aspects "Theory is very important", "Evaluations of student performance are done regularly, within the prescribed period", "Lecturer speaking skills are not relevant, but the speech content is important", "Questions are asked at the end of a class" and "The academic has to inform students about the latest developments regarding the course", the opposites of the mentioned aspects: "The academic talks less about theory, but gives more examples" (the average rating was 2.82), "The academic evaluates student performance early" (2.63), "The academic can speak in an inspiring manner" (2.25), "Questions may be asked during the entire class" and "The academic is able to inform students about all the latest developments in the university" (2.68) were more important for most of the students. This indicates that students in Latvia agree with the values of Millennial students in respect to an ideal academic, i.e. such factors as the ability of the academic to inspire students and make them interested in any particular topic in order to comprehend the topic's idea and significance. The academic's ability to provide knowledge beyond textbooks or give real-life examples from the industry is important as well.

However, most of the students were not able to give a concrete answer regarding taking lecture notes and giving marks to students and were unable to choose between the aspect "Taking lecture notes are not obligatory during classes" and the aspect "Taking lecture notes are obligatory during classes" (the average rating was 4.17) as well as between the aspect "The academic orally evaluates every student's achievements regularly" and the aspect "The academic performs student evaluations only formally, giving marks to the students" (4.17). The results acquired were quite contradictory because, as mentioned above, an inspiring academic who supplied all the materials in the environment of e-learning and evaluated student performance early was important for the students. However, the students were not sure about the roles of formal and informal evaluations performed and about taking lecture notes during their classes, yet they expected that the content of their courses would be available in the virtual environment. The research results indicated that the students' value orientation was not stable and they unanimously favoured neither Millennial nor traditional values.

As regards the role of fellow students, the students mainly reflected the characteristics of the Millennial generation, as they perceived their fellows as friends (the average rating was 2.19). Extracurricular events jointly held with fellow students (the average rating was 2.52), fellow students' help with studies (2.37) and an opportunity to communicate via social networks (2.77) were important as well. It is interesting that parental support in studies was relatively important (the average rating was 3.34), which indicated the dependence of Millennial generation students on their families and the role of their families in their lives.

An analysis of the organisation and management of the process of their ideal studies showed that the students' opinions were relatively diverse and varied, which was evidenced by the standard deviation 
that in some instances reached a value of 1.9, indicating the instability of the average value and respondent differences. Higher ratings were given to the use of IT in classes (the average rating was 2.48) and the variation of teaching methods during one class (2.61). However, the opinions were more diverse regarding whether students should influence various aspects related to the study process through giving them an opportunity to determine the content of courses, a timetable of classes and the frequency of attendance of classes or to suggest ideas for tackling some problems. Most of the students believed that they had to be given an opportunity to influence everything (the average rating ranged from 3.10 to $3.89)$, while a relatively high percentage of the students (20-30\%) were rather in favour of the right of an academic to determine all the above-mentioned, thereby considering the academic to be an authority relative to students.

In the students' opinion, their studies have to be cheerful and entertaining, instead of serious (the average rating was 3.31). It was agreed by $57 \%$ of the respondents, while $25 \%$ could not give a concrete answer. In view of the fact that a third relied on their academic as an authority, it was possible to conclude that the "factor of entertainment" in their studies was expected from someone who delivered a lecture in front of the audience instead of from themselves.

When rating various aspects of higher education, the variance in the engineering students' opinions indicated the heterogeneity of this group and differences in value orientation. It was reflected in each aspect's average rating value, which mainly ranged from 3 to 4 and indicated the tendency of students to be relatively more in favour of the Millennial generation values in education, yet this support was not absolute. The variance in some aspects was so great that each category from 1 to 7 was represented by a similar number of respondents, and a category having a predominance of supporters or the aspect mode tended to shape the average value.

\section{Conclusions}

1. The Millennial generation is currently enrolled in higher education with a new set of characteristics and values. In the scientific literature, the Millennial generation is identified as a generation that was born from 1980 to 1999, yet in Latvia this generation emerged only in the early 1990s, i.e. after the collapse of the Soviet Union. Millennial students demonstrate the values and the way of thinking of the Millennial generation, whereas their predecessors (Generation X) have traditional values and a traditional perspective regarding higher education.

2. Students in Latvia were relatively more in favour of Millennial generation values rather than traditional values in higher education, yet their support was not absolute. The students demonstrated agreement with such essential aspects for the Millennial generation as the availability of technologies and the Internet for an effective study process, teaching personnel's knowledge of their discipline and ability to make students interested in a topic and give fast feedback, as well as an attractive study process.

3. In Latvia, Millennial students' opinions were not similar with regard to the roles of an academic and a student in the study process - in determining the content of a study course, a timetable of classes and the attendance of classes. Most of the students believed that they had to be given an opportunity to influence everything, while a third were rather in favour of the role of an academic as an authority in the study process

4. In view of the fact that in Latvia Millennial students' value orientation is not stable and they unanimously favour neither Millennial nor traditional values, any academic faces a great challenge to work with this generation. Today's educators/lecturers must understand their Millennial generation audience. By understanding Millennial students and how they learn, the educator will be more successful in creating a learning centered environment.

5. Further studies should be implemented to deeper understand students' understanding of and expectations towards higher education and to identify possibilities for how this understanding could be realized in higher education in Latvia.

\section{Acknowledgement}

The paper was supported by the National Research Programme 5.2 "Economic Transformation, Smart Growth, Governance and Legal Framework for the State and Society for Sustainable Development - a New Approach to the Creation of a Sustainable Learning Community (EKOSOC- 
LV)". The research was conducted within the project 5.2.7 "Involvement of the society in social innovation for providing sustainable development of Latvia" of the National Research Program EKOSOC-LV.

\section{References}

1. Murphy E.F., Gibson J.W., Greenwood R.A. Analyzing generational values among managers and non-managers for sustainable organizational effectiveness. SAM Advanced Management Journal, Winter, 2010, pp. 33-55.

2. Monaco M., Martin M. The Millennial Student: A New Generation of Learners. Athletic Training Education Journal, vol. 2, 2007, pp. 42-46.

3. Bracy C., Bevill S., Roach T.D. The millennial generation: recommendations for overcoming. Proceedings of the Academy of Educational Leadership, vol. 15(2), 2010, pp. 21-26.

4. Brock C. Comparative Education and the Geographical Factor. Journal of International and Comparative Education, vol. 2(1), 2013, pp. 9-17.

5. Jung J.Y., Lin W.Y., Kim Y.C. The dynamic relationship between East Asian adolescents' use of the internet and their use of other media. New Media \& Society, vol. 14(6), 2012, pp. 969-986.

6. Koeller M. From Baby Boomers to Generation Y Millennials: Ideas on How Professors Might Structure Classes for this Media Conscious Generation. Journal of Higher Education Theory and Practice, vol. 12(1), 2012, pp. 77-83.

7. Kahl C. Students' dream of a "perfect" learning environment in private higher education in Malaysia: An exploratory study on "education in private university in Malaysia". Procedia - Social and Behavioral Sciences, vol. 123, 2014, pp. 325-332.

8. Kupperschmidt B.R. Multigeneration employees: strategies for effective management. The Health Care Manager, vol. 19 (1), 2000, pp. 65-76.

9. Ozkan M., Solmaz B. The Changing Face of The Employees - Generation Z and Their Perceptions of Work (A Study Applied to University Students). Procedia Economics and Finance, vol. 26, 2015, pp. 476-483.

10. Schuman H., Scott J. Generations and collective memories. American sociological review, vol. 54 (3), 1989, pp. 359-381.

11. Strauss W., Howe N. Generations: A History of America's Future, 1584 to 2069. New York: Marrow, $1991.521 \mathrm{p}$.

12. Howe N., Strauss W. Millennials Go to College. Great Falls, VA: American Association of Collegiate Registrars and Life Course Associates, 2007. 228 p.

13. Mcmillan S.J. Coming of age with the internet: A qualitative exploration of how the internet has become an integral part of young people's lives. New Media \& Society, vol. 8(1), 2006, pp. 73-95.

14. Wessels P., Steenkamp L. Generation Y students: Appropriate learning styles and teaching approaches in the economic and management sciences faculty. South African Journal of Higher Education, vol. 23(5), 2009, pp. 1039-1058.

15. White G., Kiegaldie D. Gen Y learners: just how concerned should we be? The clinical teacher, vol. 8(4), 2011, pp. 263-266.

16. Martin C.A. Getting high on Gen Y: How to Engage the Entitlement Generation. Career Planning and Adult Development Journal, vol. 24(3), 2008, pp. 19-23.

17. Schofield C.P., Honoré S. Generation Y and learning. The Ashridge Journal, Winter, 2010, pp. 26-32.

18. Ceobanu C., Boncu S. The challenges of the mobile technology in the young adult education. Procedia - Social and Behavioral Sciences, vol. 142, 2014, pp. 647-652.

19. Hendrix M., Bitely A. The Millennial Generation research review. National Chamber Foundation, 2012, $40 \mathrm{p}$.

20. Alexander C. A study of the cognitive determinants of generation Y's entitlement mentality. Academy of Educational Leadership, vol. 16(2), 2011, pp. 63-69.

21. Goldgehn L.A. Generation Who, What, Y? What You Need to Know About Generation Y. International Journal of Educational Advancement, vol. 5(1), 2004, pp. 24-34.

22. Prensky M. Digital natives, Digital immigrants. On the Horizon, vol 9, No 5, 2000, pp. 16-22.

23. Narasuman S., Yunus M.R.M., Kamal A.A. Net generation student teachers: How tech-savvy are they? Asia Pacific Journal of Educators and Education, vol. 26(1), 2011, pp. 71-89.

24. Coomes M., DeBard R. Serving the Millennial Generation. San Francisco: Jossey-Bass, 2004. $112 \mathrm{p}$. 